\title{
THE
}

UNIVERSITY

University of Rhode Island

OF RHODE ISLAND

DigitalCommons@URI

2-7-2015

\section{Herbivore Impacts on Two Morphologically Similar Bloom- Forming Ulva Species in a Eutrophic Bay}

Michele Guidone

Carol S. Thornber

University of Rhode Island, thornber@uri.edu

Kathryn L. Van Alstyne

Follow this and additional works at: https://digitalcommons.uri.edu/bio_facpubs

The University of Rhode Island Faculty have made this article openly available.

Please let us know how Open Access to this research benefits you.

This is a pre-publication author manuscript of the final, published article.

Terms of Use

This article is made available under the terms and conditions applicable towards Open Access

Policy Articles, as set forth in our Terms of Use.

Citation/Publisher Attribution

Michele Guidone, Carol Thornber, and Kathryn Van Alstyne. (2015). "Herbivore impacts on two morphologically similar bloom-forming Ulva species in a eutrophic bay." Hydrobiologia. Available at:

http://link.springer.com/article/10.1007/s10750-015-2204-6

This Article is brought to you for free and open access by the Biological Sciences at DigitalCommons@URI. It has been accepted for inclusion in Biological Sciences Faculty Publications by an authorized administrator of DigitalCommons@URI.For more information, please contact digitalcommons-group@uri.edu. 
2 Herbivore impacts on two morphologically similar bloom-forming Ulva species in a eutrophic

11 *Author for correspondence: michele.guidone@armstrong.edu, T: 912-344-3183, 


\section{Abstract}

18 Herbivore impacts on macrophyte growth vary with the identity of the herbivores and

19 macrophytes, as well as under different abiotic conditions. This interaction is further complicated

20 by anthropogenic alterations to the environment, such as eutrophication. In this study, we utilized

21 in situ herbivore exclusion experiments and mesocosm feeding preference assays to examine the

22 impacts of different herbivores on the growth of two morphologically similar, co-occurring

23 macroalgal bloom Ulva species in a nutrient-rich environment. We found herbivory had a

24 measurable impact on Ulva biomass, though the rate of consumption rarely surpassed growth for

25 either Ulva species. We determined that the primary herbivores within the blooms were

26 amphipods and mud crabs, and that their effects varied among study sites and months. Our

27 results also confirmed that, even with a diverse suite of consumers, Ulva blooms are capable of

28 escaping herbivore control, particularly early in the growing season when growth rates peak and

29 herbivore activity is limited. Furthermore, our experiments revealed species-specific feeding

30 preferences among herbivores, as well as differences in growth rates and chemistry between the

31 two Ulva species, which likely influence bloom dynamics.

34 Keywords: Algal bloom, Eutrophication, Green tide, Herbivore, Top down control, Ulva 


\section{Introduction}

The structure of macrophyte communities is affected by the availability of resources and

37 the strength of herbivory; the relative contribution of these opposing forces can fluctuate

38 considerably among different habitats (Shurin et al., 2002; Hillebrand et al., 2007; Gruner et al.,

39 2008). Even among similar habitat types, the relationship between resource availability and

40 herbivore pressure can vary depending upon the identity, diversity, and abundance of individual

41 macrophyte and herbivore species present (e.g. Boyer et al., 2004; Burkepile \& Hay, 2006; Sala

42 et al., 2008; Vermeij et al., 2010; McLenaghan et al., 2011).

43 Anthropogenic impacts, including nutrient pollution, can significantly alter the relative

44 influence of resource availability and herbivory on macroalgal communities. Within coastal

45 ecosystems, eutrophication can promote the growth of fast growing ephemeral macroalgal

46 species at the expense of perennial macroalgae and seagrasses (Valiela et al., 1997; Hauxwell et

47 al., 2001; Worm \& Lotze, 2006). In some instances, herbivory offsets this increase in biomass,

48 preventing widespread changes to the ecosystem (Geertz-Hansen et al., 1993; Neckles et al.,

49 1993; Williams \& Ruckelshaus, 1993; Korpinen et al., 2007). However, in many cases nutrient

50 enrichment enables macroalgal growth to surpass herbivore control (Horne et al., 1994;

51 Hauxwell et al., 1998; Morgan et al., 2003; Worm \& Lotze, 2006; Fox et al., 2012), resulting in

52 macroalgal blooms. Moreover, persistent eutrophication can further lessen herbivore control by

53 decreasing herbivore functional responses to the higher algal nutrient concentrations that occur

54 with nutrient pulses (Russell \& Connell, 2007) and increasing the occurrence of hypoxic events

55 that result in herbivore mortality (Hauxwell et al., 1998; Berezina et al., 2007).

56 Beyond their potential to limit the occurrence or severity of a macroalgal bloom event,

57 herbivores also have the potential to alter algal diversity or richness within a bloom by 
58 preferentially consuming one or more algal species. This preference can be driven by algal

59 morphology, chemical defenses, or nutritional content (e.g. Van Alstyne et al., 2001; Van

60 Alstyne \& Houser, 2003; Thornber et al., 2008), and results in an increase of less palatable

61 species. For example, Lotze \& Worm (2000) observed that herbivores in the Baltic Sea preferred

62 to graze Ulva spp. (formerly Enteromorpha) over Pilayella littoralis, resulting in the dominance

63 of $P$. littoralis in Baltic blooms. However, mesocosm assays demonstrated that this preference

64 was only exhibited by certain herbivore species. Similarly, Nelson et al. (2008) found that the

65 distributional pattern of attached bloom-forming Ulva and Ulvaria in Washington, USA was due

66 to a combination of preferences by subtidal herbivores for Ulva and abiotic conditions in the

67 intertidal zone that restricted the range of chemically defended Ulvaria. Consequently, Ulva was

68 more abundant in the intertidal zone, while Ulvaria proliferated in the subtidal zone. These

69 studies highlight both the importance of herbivory in determining the macroalgal species present

70 within blooms, as well as how herbivore impacts can vary with herbivore identity and

71 environmental conditions.

72 Macroalgal blooms are an annual occurrence within many shallow, eutrophic areas of

73 Narragansett Bay, Rhode Island. In contrast to previously studied multi-species blooms, which

74 contained species from different genera that were distinctly different in morphology and/or

75 chemistry (eg. Lotze \& Worm 2000; Nelson et al. 2008), these blooms are primarily composed

76 of the morphologically similar Ulva compressa Linnaeus and U. rigida C. Agardh. Which (if

77 either) of these Ulva species is dominant within these blooms varies spatially and temporally

78 (Guidone \& Thornber, 2013), and it is currently unknown how abiotic and biotic factors

79 influence interactions between these species. Surveys of bloom sites within Narragansett Bay

80 indicated differences in the invertebrate community present within the blooms (Guidone and 
81 Thornber, unpubl. data), offering a potential explanation for site-to-site differences in bloom

82 species composition. Therefore, to explore herbivore impacts within these blooms, we conducted

83 in situ herbivore exclusion experiments as well as a series of mesocosm feeding assays to

84 determine: 1) whether herbivores that co-occur with Ulva blooms in the field have a measurable

85 impact on Ulva biomass, 2) how the impacts of invertebrate grazing vary among species, sites of

86 varying bloom severity, and throughout the growing season, 3) the consumption rates and

87 feeding preferences of several abundant herbivore species on $U$. compressa and U. rigida, and 4)

88 any physical or chemical differences between the two Ulva species that might explain herbivore

89 preferences. We discuss our results within the context of the role of invertebrates in impacting

90 algal bloom severity and species composition.

91

\section{Materials and Methods}

\section{Study locale and species}

94 Narragansett Bay, Rhode Island, is a well-studied estuary; the northern portions of the

95 bay, as well as several of the bay's subestuaries, are heavily impacted by anthropogenic nutrient

96 and chemical pollution (e.g. Granger et al., 2000; Calabretta \& Oviatt, 2008; Deacutis, 2008;

97 Oczkowski et al., 2008). Our field sites were located within Greenwich Bay, Rhode Island (Fig.

98 1), a subestuary of Narragansett Bay that experiences annual blooms dominated by $U$. compressa

99 and U. rigida (Guidone \& Thornber, 2013). Both U. compressa and U. rigida are distromatic

100 blades lacking any distinguishing macroscopic features. Therefore, prior to the start of each

101 experiment species identity of all blades was determined in the laboratory using cellular features

102 based on previous molecular studies (Hofmann et al., 2010; Guidone et al., 2013). 
All invertebrates used in our mesocosm feeding assays were collected from Oakland

104 Beach Cove, Warwick, Rhode Island (Fig. 1). The species used in the mesocosm experiments

105 were selected based upon their presence during our pilot in situ herbivore exclusion cage

106 experiments (see below). Although abundant at all of our sites, mud snails (Ilyanassa obsoleta)

107 were not included in these assays as our data indicate that, in this system, they rarely consume

108 distromatic Ulva spp. (Guidone et al., 2010, 2012).

109

110 In situ herbivore exclusions

111 We conducted in situ herbivore exclusion experiments monthly from May-August 2009

112 and June-July 2010 at three field sites: Chepiwanoxet (CH), Warwick City Park (WCP), and

113 Oakland Beach Cove (OBC; Fig. 1). These sites were selected to represent a range of distromatic

114 Ulva bloom severity (low at $\mathrm{CH}$, medium at WCP, and high at $\mathrm{OBC}$ ) based on patterns of Ulva

115 wrack accumulation (Guidone and Thornber, personal observation). WCP and OBC were located

116 nearer to one another than either was to $\mathrm{CH}$, with WCP and $\mathrm{OBC}$ approximately $250 \mathrm{~m}$ apart on

117 opposite sides of a heavily impacted cove and $\mathrm{CH}$ in a separate portion of Greenwich Bay

118 approximately 3,000 $\mathrm{m}$ away. Cages at $\mathrm{CH}$ and WCP were located at mean depths of 40-60 $\mathrm{cm}$

119 at low tide and were placed adjacent to areas where Ulva wrack accumulates on shore. Cages at

120 OBC were at a mean depth of 20-30 $\mathrm{cm}$ at low tide; OBC cages were located in an area

121 frequently inundated by drift Ulva. Herbivore exclusion cages were placed $30 \mathrm{~m}$ offshore of the

122 mean low tide line, ensuring continual submersion throughout each experiment. Starting with the

123 June 2009 experiment, water temperature was measured every half hour throughout each

124 experiment at each site using temperature data loggers (Tidbit v2, Onset, Massachusetts, USA).

125 Mean daily temperatures during 2009 and 2010 were analyzed for differences among sites and 
months using two-way ANOVAs (JMP version 8, SAS Institute Inc., North Carolina, USA). To

127 estimate differences in dissolved inorganic nitrogen (DIN) availability among the sites, we

128 collected a single water sample from each site at the conclusion of each in situ experiment. DIN

129 levels were determined with a segmented flow autoanalyzer (model 303A, Astoria Pacific

130 International, Oregon, USA) by the University of Rhode Island's Watershed Watch.

131 In 2009, we examined herbivore impacts on Ulva compressa. For these experiments, we

132 placed a single pre-weighed blade of $U$. compressa within a mesh cage $(12.7 \mathrm{~cm} \times 8.3 \mathrm{~cm} \times 6.4$

$133 \mathrm{~cm})$. Prior to weighing, all blades were spun to a consistent dryness in a salad spinner

134 (approximately 20 rotations). Blade wet masses ranged from 0.7-1.0 g. Cages were constructed

135 from a $1 \mathrm{~cm}$ plastic frame covered with one of three mesh sizes ( $\mathrm{n}=5$ for each mesh size). Pilot

136 studies conducted during 2008 indicated that these mesh sizes differentially excluded

137 invertebrates, creating three different communities among the cages. The smallest mesh $\left(1 \mathrm{~mm}^{2}\right.$

138 pore opening) excluded all invertebrates except amphipods, isopods, polychaetes, and juvenile

139 (<3 mm carapace width) mud crabs. The medium mesh $\left(16 \mathrm{~mm}^{2}\right.$ pore size) excluded large mud

140 crabs, hermit crabs, and large mud snails, allowing in shrimp, small mud crabs $(<14 \mathrm{~mm}$

141 carapace width), and small mud snails. The largest mesh (100 $\mathrm{mm}^{2}$ pore size $)$ excluded only

142 large predatory crabs and fish. Cages were secured by cable tying them to a PVC stake that was

143 driven securely into the substrate.

144 Cages remained in the field for nine to ten days, after which they were retrieved with all

145 of their contents; previous studies have used similar time frames to measure herbivore impacts

146 (eg. Lotze \& Worm 2000; Nelson et al. 2008). To retain all mobile invertebrates, we placed each

147 cage within a plastic gallon zipper bag while the cage was still submerged. U. compressa final

148 wet mass was measured and all invertebrates found within the cages were counted and identified 
149 to the family or species (when possible) level. In addition, to determine if potential herbivores

150 avoided entering the cages, we sampled co-occurring invertebrate densities at each field site on

151 the final day of each experiment. Invertebrate density was sampled with a $40 \mathrm{~cm}$ diameter mesh

152 net ( $1 \mathrm{~mm}$ pore diameter) at $3 \mathrm{~m}$ intervals along a $30 \mathrm{~m}$ subtidal transect positioned

153 perpendicular to the shoreline. Additionally, we recorded the water depth of each sample.

154 During pilot studies, we determined that mesh sizes smaller than $1 \mathrm{~mm}^{2}$ restricted water

155 flow and light penetration, resulting in limited Ulva growth. Consequently, we were unable to

156 include a non-herbivore growth control treatment at our field sites. Therefore, to ensure the

157 different cage mesh sizes did not differentially impact Ulva growth, we monitored growth within

158 five cages of each mesh type held in seawater tables at the University of Rhode Island's Bay

159 Campus (described below). These concurrent cage mesh controls were run during each

160 experiment in 2009 and 2010.

161 In 2010, we examined herbivore impacts on both $U$. compressa and $U$. rigida. Within

162 each herbivore exclusion cage, we placed a known wet mass of both species. To accommodate

163 the additional Ulva biomass, we constructed cages with slightly larger dimensions $(10 \times 10 \times 10$

$164 \mathrm{~cm})$. All other methods were the same as described above.

165 We analyzed the change in $U$. compressa biomass during the 2009 experiments using a

166 three-way ANOVA for differences among months, sites, and cage types. For our 2010

167 experiments, the change in U. compressa and U. rigida biomass was analyzed for differences

168 among species, months, sites, and cage types using a fully factorial nested ANOVA, with species

169 nested within cage type to account for variation among cages. All data were tested for normality

170 and homogeneity of variance and transformed to meet these assumptions as needed. In addition,

171 we assessed the differences in invertebrate assemblages between our exclusion cages and net 
172 samples using a one-way analysis of similarity (ANOSIM) with subsequent similarity of

173 percentages (SIMPER) analysis. Invertebrate composition within the cages during each month of

174 the experiment was further analyzed for differences among the study sites and cage types using a

175 two-way crossed ANOSIM and SIMPER analysis. Prior to ANOSIM and SIMPER analyses,

176 data were fourth-root transformed to increase the importance of rare species and Bray-Curtis

177 similarities were calculated. All parametric statistics were conducted using JMP, while ANOSIM 178 and SIMPER analyses were conducted with PRIMER-E (version 6, Primer-E Ltd., Plymouth 179 UK).

180

Feeding preference assays

182 To determine herbivore feeding rates and assess whether U. compressa and U. rigida

183 differed in their palatability, we conducted a series of paired-choice feeding experiments using

184 each of six herbivores found at our field sites: juvenile (length $<1 \mathrm{~cm})$ Nereidae polychaetes $(6$

185 replicates), the amphipod Gammarus mucronatus (6 replicates), the hermit crab Pagurus

186 longicarpus (7 replicates), the grass shrimp Palaemonetes pugio (8 replicates) and P. vulgaris

187 (10 replicates), and the mud crab Panopeus herbstii (8 replicates; carapace width 9-18 mm). For

188 each experiment, a single herbivore species was placed in a mesocosm with a piece of $U$.

189 compressa and a piece of $U$. rigida of known wet mass (2-5 $\mathrm{mg}$ each). Due to the size disparity

190 of our herbivores, we employed two mesocosm designs. For larger species (shrimp, mud crabs,

191 and hermit crabs), we used 2.5 L plastic containers with mesh-covered holes in the sides for

192 seawater flow; these were held in outdoor, flow-through seawater tables at the University of

193 Rhode Island's Bay Campus (Narragansett, RI, USA). The seawater tables were supplied with

194 filtered, ambient temperature seawater from Narragansett Bay. Smaller invertebrates (amphipods 
195 and polychaetes) were placed within $250 \mathrm{ml}$ shallow glass bowls with filtered, room temperature 196 (approximately $21^{\circ} \mathrm{C}$ ) seawater and an air stone; seawater was changed daily for the duration of

197 these experiments. In addition, experiments utilizing the smaller herbivores, as well as the $P$. 198 pugio experiment, included two individuals per replicate mesocosm, while mesocosms with 199 larger species contained a single individual.

200 Each paired-choice experiment ran for 3 days, except for the $P$. pugio trial, which ran for

2017 days to ensure no feeding occurred (see 'Results'). To account for autogenic changes in Ulva

202 blade wet mass, an equal number of non-herbivore controls were run concurrently with each 203 experiment in identical containers. In experiments where control Ulva blades grew significantly,

204 we adjusted the final wet mass of all thalli by the amount of growth observed in the controls.

205 Results of each paired-choice assay were analyzed using matched pairs t-tests.

206

207 Characteristics of Ulva compressa and Ulva rigida

208 To determine if algal chemical or physical properties might be responsible for feeding 209 preferences, we assessed several characteristics that may influence Ulva palatability. For each

210 herbivore exclusion experiment, we measured Ulva organic content as the percent ash-free mass

211 of each thallus by combusting dried tissue samples in a muffle furnace at $500^{\circ} \mathrm{C}$ for two hours

212 (Thornber et al., 2008). Organic content for 2009 was analyzed for differences among months,

213 cage types, and sites using a three-way repeated measures ANOVA that compared organic

214 content values from the start and end of each experiment. Data from 2010 were analyzed for

215 differences among species, months, cage types, and sites with a fully-factorial repeated measures

216 ANOVA, with species nested within cage type. 
In addition, we determined the dimethylsulfoniopropionate (DMSP; a known chemical

218 precursor to herbivore deterrents) levels (as \% of dry weight) of U. compressa and U. rigida

219 blades collected in June $(n=10)$ and October $2010(n=8)$. To measure DMSP, we first dried the

220 algae at $60^{\circ} \mathrm{C}$ for seven days and then shipped them to the Shannon Point Marine Center

221 (Anacortes, WA). Approximately $0.1 \mathrm{~g}$ of each piece was weighed and sealed in a gas-tight vial

222 with $4 \mathrm{ml}$ of $4 \mathrm{~N}$ sodium hydroxide. The vials were stored in the dark overnight in order to

223 hydrolyze the DMSP, which resulted in the cleavage of DMSP and the production of the volatile

224 compound dimethylsulfide (DMS). DMS concentrations were determined in the headspace of the

225 vials by injecting $10 \mu \mathrm{L}$ headspace samples into an SRI GC equipped with a Chromasil 330

226 column in a $90^{\circ} \mathrm{C}$ oven and a flame photometric detector $\left(125^{\circ} \mathrm{C}\right)$. Commercially obtained DMSP

227 (Center for Analysis, Spectroscopy and Synthesis, University of Groningen) was used as a

228 standard. DMSP results were analyzed via two-way ANOVA for differences among species and

229 collection date.

230 Lastly, we determined Ulva blade tissue toughness for ten blades of each species

231 collected from WCP in September 2009. Tissue toughness was determined using a tissue

232 penetrometer to measure ten randomly selected locations on each blade (Duffy \& Hay 1991);

233 results for each blade were averaged prior to analysis by t-test.

\section{Results}

236 Herbivore exclusion experiments - 2009

237 In our 2009 herbivore exclusion experiments, Ulva compressa growth differed

238 significantly among months, sites, and cage types (Fig. 2, Table 1a). On average, U. compressa

239 grew 2.5 to 3 times faster at $\mathrm{CH}\left(\right.$ mean $\left.121.59 \mathrm{mg} \mathrm{d}^{-1}\right)$ and $\mathrm{OBC}\left(\right.$ mean $\left.110.37 \mathrm{mg} \mathrm{d}^{-1}\right)$ than at 
240 WCP (mean $40.03 \mathrm{mg} \mathrm{d}^{-1}$ ), with a maximum mean growth rate in May of $407.52 \pm 31.65 \mathrm{mg} \mathrm{d}^{-1}$

241 at OBC. Among the cage types, U. compressa grew an average of $35-40 \%$ more in the large and

242 medium mesh cages than in the small mesh cages, though this was largely driven by the

243 significant growth differences among the cage types in May. Our generalized linear model for

244 growth rate of cage mesh controls yielded a nonsignificant whole model response $\left(F_{11,48}=1.79\right.$,

$245 P=0.081$; mean growth $\left.=99.73 \pm 5.97 \mathrm{mg} \mathrm{d}^{-1}\right)$, demonstrating a lack of difference in algal

246 growth rate due to abiotic variation, such as light levels and water flow, caused by the cage mesh

247 types. This indicates that in situ differences among cage types within a site were due to the

248 differential herbivory of the invertebrate communities the cages created.

249 Invertebrate assemblages within the cages at WCP and OCB were exceedingly similar to

250 each other and significantly different from $\mathrm{CH}$ during all months in 2009 (see Online Resource

251 Table S1a). Between site dissimilarity was mostly accounted for by the varying abundance of

252 amphipod taxa, with polychaetes and panopeid mud crabs accounting for a majority of the

253 remaining dissimilarity (Fig. 3, Online Resource Table S2a). Additionally, assemblages in the

254 small mesh cages were significantly different from those in the medium and large mesh cages in

255 every instance except July, where invertebrates within the small and medium mesh cages were

256 similar (Online Resource Table S1b). Significant differences between the invertebrates within

257 the large and medium mesh cages were only observed during June and August 2009 (Online

258 Resource Table S1b). Although found across all cage types, amphipod taxa were most abundant

259 within the small mesh cages, while panopeid mud crabs and Palaemonetes spp. shrimp were

260 most abundant in the large and medium mesh cages. Nereid polychaetes showed no clear

261 preference for any cage type (Fig. 3, Online Resource Table S2b).

262 
In 2010, Ulva growth again differed significantly among sites and cage types, as well as

265 species (Fig. 4, Table 1b). In addition, when averaged across all sites and both months, $U$.

266 compressa grew approximately 2.5 times more than U. rigida. As in 2009, our generalized linear

267 model for growth rate of cage mesh controls yielded a nonsignificant whole model response $\left(F_{17}\right.$,

$26858=0.94, P=0.54$ ), although mean $U$. compressa growth rates (June: $57.67 \mathrm{mg} \mathrm{d}^{-1}$ and July:

$26975.21 \mathrm{mg} \mathrm{d}^{-1}$ ) in these cage mesh controls were approximately $60 \%$ higher than $U$. rigida (June:

$270 \quad 36.23 \mathrm{mg} \mathrm{d}^{-1}$ and July: $\left.45.07 \mathrm{mg} \mathrm{d}^{-1} ; F_{1,17}=8.07, P=0.006\right)$.

271 As in 2009, mean Ulva growth for all months was highest at CH $\left(65.04 \pm 19.64 \mathrm{mg} \mathrm{d}^{-1}\right)$,

272 although growth was lowest at OBC (mean $\left.7.44 \pm 18.49 \mathrm{mg} \mathrm{d}^{-1}\right)$ rather than WCP $(18.87 \pm 16.24$

$273 \mathrm{mg} \mathrm{d}^{-1}$; Fig. 4). Invertebrate assemblages among the months and cage types showed similar

274 patterns to those found in 2009 (Online Resource Table S1c, d); however, the abundance of 275 amphipods in the families Aoridae and Gammaridae were notably higher at WCP and OBC, 276 while amphipods in the family Corophiidae were notably higher at CH in July 2010 (Fig. 3,

277 Online Resource Table S2a).

Herbivore exclusion experiments - General patterns Mean water temperatures in 2009 were significantly different among all months $\left(\mathrm{F}_{2,8}=\right.$ 281 106.31, $P<0.0001)$ and significantly higher at $\mathrm{OBC}$ than at $\mathrm{CH}\left(\mathrm{F}_{2,8}=6.24, \mathrm{p}=0.003\right.$; Online 282 Resource Table S3). However, the difference in mean daily temperature among the sites within 283 any individual month was less than $1.5^{\circ} \mathrm{C}$. Mean water temperatures in 2010 were significantly 284 higher in July than in June $\left(\mathrm{F}_{1,5}=20.44, \mathrm{p}<0.0001\right)$ but did not differ among sites $\left(\mathrm{F}_{2,5}=2.18\right.$, $285 \mathrm{p}=0.12 ;$ Online Resource Table S3). 
Mean water nitrate levels in 2009 were markedly higher at WCP $\left(118.25 \pm 43.97 \mu \mathrm{g} \mathrm{L}^{-1}\right)$

287 and $\mathrm{OBC}\left(151.5 \pm 53.78 \mu \mathrm{g} \mathrm{L}^{-1}\right)$ than $\mathrm{CH}\left(25.00 \pm 6.24 \mu \mathrm{g} \mathrm{L}^{-1}\right)$. Mean water nitrate levels were

288 lower in 2010, with less variation among sites $(\mathrm{CH} 11.00 \pm 4.00$; WCP $12.00 \pm 1.00$; OBC 25.00

$\left.289 \pm 14.57 \mu \mathrm{g} \mathrm{L}^{-1}\right)$.

290 In both 2009 and 2010, the invertebrate community found within the exclusion cages

291 differed significantly from those found via net sampling $(2009$ global $\mathrm{R}=0.77, P=0.001 ; 2010$

292 global $\mathrm{R}=0.719, P=0.001$; Table S4). This difference was mostly due to the greater abundance

293 of Ilyanassa obsoleta within net samples and a greater abundance of amphipods, mud crabs, and

294 polychaetes within the cages (Online Resource Table S4). A greater abundance of shrimp and

295 hermit crabs within the net samples also contributed to the dissimilarity (Online Resource Table

296 S4).

297 Additionally, in 2009 and 2010 we found no relationship between the growth rate of

298 either Ulva species and the total number of invertebrates found within the exclusion cages

299 (Online Resource Fig. S5). Ulva growth rates were also not related to invertebrate species

300 richness or diversity (Shannon H') within the cages (data not shown). When we examined the

301 relationship between Ulva growth and individual taxa by month, significant negative

302 relationships $\left(r^{2}=0.13\right.$ to 0.39$)$ were found between $U$. compressa growth and the abundance of

303 amphipods in the families Gammaridae and Melitidae in July 2009, and growth rates for both

304 Ulva species with mud crab abundance in July 2010 (Online Resource Fig. S6).

Feeding preference assays

307 Herbivore consumption of Ulva thalli was readily apparent for all herbivores except

308 Palaemonetes pugio (Fig. 5). Thallus consumption was evident due to grazing marks on the thalli 
309 and/or the continual presence of green hued feces within the mesocosms. Of the five herbivores

310 that consumed Ulva, both Gammarus mucronatus and Panopeus herbstii consumed significantly

311 more $U$. compressa than $U$. rigida $\left(G\right.$. mucronatus $t_{5}=6.106, P=0.0017 ; P$. herbstii $t_{7}=3.22, P$

$312=0.015$; Fig. 5). P. herbstii also had the highest consumption rate, consuming an average of 5.88

$313 \mathrm{mg} \mathrm{d}^{-1}$ of $U$. compressa and $1.25 \mathrm{mg} \mathrm{d}^{-1}$ of $U$. rigida. In contrast to the other assays, both Ulva

314 species grew in the $P$. pugio assay, with $U$. rigida growing approximately $6 \mathrm{mg} \mathrm{d}^{-1}$ more in the

315 presence of $P$. pugio than in the control treatment $\left(t_{7}=-2.71, P=0.03\right)$.

317 Characteristics of Ulva compressa and Ulva rigida

318 In 2009, the organic content of $U$. compressa tissue was lowest during May (67.59 \pm

$3190.64 \%)$ and highest in August $\left(77.34 \pm 0.80 \% ; F_{3,129}=56.37, P<0.0001\right.$; Table 2). Organic

320 content also differed among sites $\left(F_{2,129}=6.06, P=0.0031\right)$. Thalli at $\mathrm{CH}($ mean $72.40 \pm 0.68 \%)$

321 had the lowest organic content for all months except July. In 2010, organic content again differed

322 among sites $\left(F_{2,100}=5.07, P=0.008\right)$, however $\mathrm{CH}$ had the highest values (mean $69.48 \pm$

$3230.89 \%$; Table 2). Additionally, U. compressa organic content (mean $68.85 \pm 0.76 \%$ ) was $2-6 \%$

324 higher than $U$. rigida (mean $65.10 \pm 1.19 \%$ ), though this difference was not significant $\left(F_{3,100}=\right.$

$3251.72, P=0.17)$. For both years, organic content did not change throughout the course of the

326 experiments (2009: $\left.F_{1,129}=0.0011, P=0.97 ; 2010: F_{1,100}=3.57, P=0.062\right)$.

327 The percent content of DMSP differed significantly between the Ulva species $\left(F_{1,53}=\right.$

$32823.69, P<0.0001)$, but the direction of this difference depended on the month in which the

329 blades were sampled (Month*Species $\left.F_{1,53}=44.25, P<0.0001\right)$. U. compressa thalli collected

330 in June 2010 had DMSP levels that were only 14\% higher (mean $1.74 \pm 0.06 \%$ ) than those of $U$. 
331 rigida (mean $1.53 \pm 0.06 \%$ ). In contrast, DMSP levels in $U$. rigida collected during October

3322010 (mean $2.39 \pm 0.09 \%$ ) were $130 \%$ higher than those of $U$. compressa (mean $1.04 \pm 0.12 \%$ ).

333 Tissue toughness did not differ between Ulva compressa and $U$. rigida $\left(t_{21}=0.68, P=\right.$

$3340.51)$

335

336 Discussion

Our results demonstrate that a wide variety of invertebrates found at bloom-impacted

338 sites consume Ulva and measurably reduce its biomass. In situ, this was evidenced by significant

339 growth differences among the cage types. Unfortunately, we were unable to include an in situ

340 herbivore exclusion cage control to assess total Ulva growth rates, since mesh sizes small enough

341 to exclude amphipods severely limited Ulva growth. However, controls run at our mesocosm

342 facility demonstrated Ulva growth rates were unaffected by the abiotic environments created by

343 the mesh sizes used in this experiment. Therefore, while the lack of a non-herbivore control

344 prevented us from calculating total herbivory, we can confidently attribute significant differences

345 in Ulva growth among cage types to the differences in the herbivore communities the cages

346 created.

347 Based on the growth differences among the cage types, the herbivores that had the largest

348 impact on Ulva growth varied monthly in both study years. Amphipods exerted the greatest

349 herbivore pressure early in the bloom season, while mud crabs, and possibly shrimp, exerted

350 equal or greater pressure later in the summer. In 2009, the largest discernable herbivore impact

351 was observed in May within the small mesh cages, which were mainly occupied by amphipods

352 and polychaetes. Throughout the remaining months of 2009, U. compressa growth was similar in

353 all cage types. While this could indicate that amphipod consumption decreased after May, it 
354 more likely represents an increase in consumption by larger herbivores found in the medium and

355 large mesh cages as 1) U. compressa in our cages grew less in these months than in May, despite 356 continued bloom proliferation at these sites (Guidone and Thornber, 2013) and 2) mud crabs

357 were more abundant in these later months.

358 We observed a similar pattern in 2010. During June 2010, Ulva in the small and medium

359 mesh cages experienced the greatest herbivore consumption, indicating amphipods were the

360 dominant herbivores. In contrast, in July 2010 greater herbivory was observed in the medium and

361 large mesh cages, which had a greater abundance of panopeid mud crabs and the shrimp

362 Palaemonetes vulgaris.

363 Of the taxa identified within the small mesh cages, amphipods in the Gammaridae family

364 had the largest detectable impact on Ulva biomass. They were the most abundant herbivore in the

365 OBC small mesh cages during May 2009 when $282.2 \mathrm{mg} \mathrm{d}^{-1}$ more biomass was consumed in the

366 small mesh than the large mesh cages. Their abundance was also negatively correlated to $U$.

367 compressa growth during July 2009. Our mesocosm feeding assays and previous study (Horne et

368 al., 1994) have confirmed Gammarus mucronatus as an Ulva consumer, and indeed, this was the

369 dominant gammarid species in our samples. Melita nitida, the predominant melitid amphipod in

370 our samples, represents another potential Ulva consumer as melitid abundance was negatively

371 correlated with Ulva growth during July 2009.

372 Within the medium and large mesh cages, the most influential herbivore taxon was

373 panopeid mud crabs. We observed a negative correlation between their abundance and Ulva

374 growth in July 2010. The mud crab Panopeus herbstii also had the highest Ulva consumption

375 rate in our mesocosm experiments, consuming an average of $7.13 \mathrm{mg} \mathrm{d}^{-1}$ of Ulva tissue.

376 Although this was the greatest per capita impact we observed in our feeding assays, it is within 
377 the range reported for other Ulva consuming mesoherbivores (e.g. Idotea baltica, 2.9-7.3 $\mathrm{mg} \mathrm{d}^{-1}$;

378 Hauxwell et al., 1998; Nicotri, 1980). Based on our SIMPER analyses and previous study (Fox et

379 al., 2012), P. vulgaris is also likely to be grazing Ulva in these cages. However, we did not

380 observe an in situ relationship between $P$. vulgaris abundance and Ulva growth during any study

381 month. Low consumption rates during mesocosm assays further indicate that $P$. vulgaris may

382 only play a small role in regulating Ulva bloom biomass in this system.

383 While herbivory had a negative impact on Ulva biomass during both years, herbivore

384 consumption rarely exceeded the rate of Ulva growth, corroborating previous studies that found

385 that herbivory could not control bloom proliferation in high nutrient areas (Horne et al., 1994;

386 Hauxwell et al., 1998; Morgan et al., 2003; Worm \& Lotze, 2006; Fox et al., 2012). Indeed, if $U$.

387 compressa were growing at the maximum rate observed during our study (503.38 $\mathrm{mg} \mathrm{d}^{-1}$ at OBC

388 during May 2009), it would take a minimum of 71 P. herbstii mud crabs or 149 G. mucronatus

389 amphipods to completely consume the daily biomass produced by a single blade of $U$.

390 compressa. Even within our cages where these species congregated, we never observed densities

391 this high. As a square meter of a bloom mat can be composed of several large blades to over 200

392 individual smaller blades (Guidone and Thornber, unpubl. data), it is easy to see how blooming

393 Ulva readily escapes the influence of herbivory. Moreover, the observed temporal mismatch

394 between the start of rapid Ulva growth in late spring and the onset of mud crab and shrimp

395 herbivory in June to July may enhance Ulva bloom proliferation in this system (Svensson et al., 396 2012).

397 Given that many herbivores appeared concentrated within our cages in comparison to our 398 net samples, it is possible that our field data overestimated the potential for herbivore control in 399 this system. However, it should be noted that our net samples rarely coincided with macrophytes 
or drifting Ulva, which serve as habitat for these types of herbivores (e.g. Norkko et al., 2000).

401 Therefore, it is also possible that our net samples represent an underestimate of the herbivore

402 abundance that would be found within an Ulva mat. If this is the case, our cages may represent a

403 better estimate of herbivore abundance within these blooms than our net samples.

404 Contrary to our expectations, Ulva growth rates were often greatest at $\mathrm{CH}$, the site that

405 we identified as least bloom impacted. Based on our limited point sampling of water DIN,

406 nutrient levels cannot explain the variation in Ulva growth among sites or months; $\mathrm{CH}$ had lower

407 DIN levels than WCP and OBC in 2009 and similar DIN levels to the other sites in 2010.

408 Differences in temperature among the sites also fail to explain differences in growth rates; mean

409 daily temperature never differed more than $1.5^{\circ} \mathrm{C}$ among the three sites. In contrast, invertebrate

410 community composition did differ significantly between $\mathrm{CH}$ and the other two sites. In

411 particular, $\mathrm{CH}$ had fewer mud crabs during most months, and a complete absence of melitid

412 amphipods except during August 2009. While growth differences among the sites may have been

413 influenced by unmeasured abiotic variables (e.g. water flow, salinity, light levels), our results

414 suggest that minor differences in the herbivore community may have a measurable impact on

415 Ulva growth among eutrophic sites.

416 Although we observed strong impacts of individual taxa on Ulva growth within particular

417 months, we did not find an overall negative correlation between Ulva growth and total

418 invertebrate abundance, nor were negative correlations between particular taxa and Ulva growth

419 consistent across all study months. This may be partially due to the study methods. Although our

420 in situ experiments provided for an estimate of relative herbivore pressure among the different

421 herbivore communities created by our cages, lack of an herbivore exclusion treatment limited our

422 ability to detect patterns in the larger data set. However, the high degree of variation found 
423 within our study among sites and months is consistent with previous work (Morgan et al., 2003)

424 and could be due to a number of additional factors.

425 First, it is possible that our assessment of the herbivore communities within the cages was

426 biased towards slower moving organisms. Fast moving animals, such as shrimp or juvenile fish, 427 may have darted from the large and medium mesh cages while they were being placed into bags

428 for transport to the laboratory. The ability of juvenile fish to quickly escape is supported by our 429 observation that Fundulus heteroclitus (a known Ulva consumer, Sly, 2013) is common at all 430 three field sites (Guidone and Thornber, unpubl. data), yet they were never present within any of 431 the cage or net samples.

432 Second, it is unlikely that all invertebrates within our cages were consuming Ulva tissue,

433 therefore a correlation between the total number of invertebrates and Ulva growth should not 434 necessarily be expected. Among the non-Ulva consumers, some may have facilitated Ulva 435 growth by consuming fouling organisms or contributing nutrients through their nitrogenous 436 wastes, further obscuring our detection of herbivory patterns. The positive influences of 437 removing fouling organisms have been demonstrated for amphipods (Kamermans et al., 2002), 438 snails (Jormalainen et al., 2003; Råberg \& Kautsky, 2008; Guidone et al., 2010, 2012;), chitons 439 (Littler et al., 1995), and aquatic insect larvae (Dudley, 1992). Mussels (Aquilino et al., 2009) 440 and snails (Guidone et al., 2012) can also facilitate macroalgal growth via nitrogenous wastes, 441 though this mechanism is unlikely to have an impact at nutrient enriched sites or sites with short 442 water residence times (Yarrington et al., 2013). Furthermore, omnivorous individuals may have 443 only occasionally consumed Ulva tissue. Even among the suspected herbivores, some may 444 choose to not consume Ulva. For examples, we observed Palaemonetes pugio would not 
445 consume any Ulva tissue during mesocosm assays, even after one week with no other food 446 source provided.

447 Last, variation within our data may have resulted from herbivore preferences that

448 fluctuate temporally or spatially with Ulva tissue quality or defensive chemistry. While we found 449 no difference in tissue toughness and only small differences in organic content, DMSP values 450 differed significantly between the two Ulva species and the direction of this difference differed 451 over time. Intraspecific DMSP values of Ulva in the Pacific Northwest have also been shown to 452 vary widely (Van Alstyne et al., 2007), and levels of DMSP in Ulva species can vary with light 453 (Karsten et al., 1991), salinity (Karsten et al., 1992), and temperature (Lyons et al., 2010). As 454 DMSP is a precursor to the herbivore deterrents acrylic acid and DMS (Van Alstyne et al., 2001; 455 Van Alstyne and Houser, 2003), if DMSP levels of $U$. compressa and $U$. rigida vary over the 456 course of the summer or among sites, then herbivore preferences may fluctuate accordingly. 457 However, it is also worth noting that a clear pattern between herbivore consumption and Ulva 458 DMSP levels could be obscured if not all herbivores in a given habitat are deterred by acrylic 459 acid or DMS (Erickson et al., 2006; Van Alstyne et al., 2009). Therefore, a detailed examination 460 of temporal and spatial patterns of Ulva DMSP levels, in conjunction with herbivore feeding 461 assays, is needed to clarify the role of DMSP in herbivore Ulva preferences and overall bloom 462 species composition in this system.

463 One consistent relationship that emerged from our $2010 \mathrm{in}$ situ experiments is that Ulva 464 rigida grew significantly less than U. compressa, even showing net biomass losses at WCP and 465 OCB during July 2010. However, two lines of evidence suggest that this is not because U. rigida 466 was consumed more than U. compressa. First, our cage controls held at our mesocosm facility 467 demonstrated that $U$. compressa growth rates were greater than those of $U$. rigida in the absence 
468 of herbivory. Had we been able to incorporate an in situ non-herbivore control, adjustments for

469 growth rates would likely indicate $U$. compressa was consumed as much, or more than, $U$.

470 rigida. Additionally, both herbivores that demonstrated a feeding preference in our mesocosm

471 paired-choice feeding assays preferred U. compressa to U. rigida.

472 Our findings highlight the complex nature of invertebrate herbivore impacts on

473 macroalgal growth when examined across months, sites, and bloom-forming species within a

474 eutrophic system. Previous studies have demonstrated that both herbivore and macrophyte

475 species identity are important factors to consider when determining herbivore impacts on

476 macrophytes (e.g. Duffy et al., 2001; Duffy \& Harvilicz, 2001). Indeed, within our mesocosm

477 experiments, we observed that two Palaemonetes species had markedly different impacts on

478 Ulva growth, with P. vulgaris consuming both Ulva species and P. pugio facilitating U. rigida

479 growth. Additionally, our results point to growth rate and palatability differences between the

480 morphologically similar $U$. compressa and $U$. rigida that likely influence species composition

481 within these Ulva blooms, similar to previous studies of multi-species blooms with

482 morphologically and/or chemically distinct species (eg. Lotze \& Worm 2000; Nelson et al.

483 2008). While closely related species may form functional groups that can have similar ecosystem

484 impacts (e.g. Steneck \& Dethier, 1994), our results support the view that the complexity within a

485 functional group may be just as relevant to ecosystem structure as differences across functional

486 groups (e.g. Nelson et al., 2008; Thornber et al., 2008; Burkepile \& Hay, 2010).

\section{Acknowledgements}

We thank C. Newton, N. Rohr, and L. Steele for their helpful comments that improved

490 this manuscript. Additional thanks to J. Burkhardt, K. Eldredge, C. Newton, E. Vincent, and A. 
491 Viveiros for their help with cage deployment and sample processing, A. Barbosa, E. Blair, C.

492 Donahue, K. Hyman, S. Rinehart, and N. Rohr for sample processing assistance, and E. Baker

493 for his assistance with the University of Rhode Island Center for Marine Life Science facilities.

494 Field experiments were conducted under Rhode Island Coastal Resources Management Council 495 permit \#s 2008-06-093, 2008-06-094, and 2008-06-095. Funding for this research was provided 496 by Bay Window (National Oceanic Atmospheric Administration), Rhode Island Sea Grant, the 497 National Science Foundation (NSF IOB-0090825), the Sounds Conservancy Quebec-Labrador 498 Foundation, and the University of Rhode Island. This material is also based upon work 499 conducted at the Rhode Island Experimental Program to Stimulate Competitive Research 500 (EPSCoR) supported Center for Marine Life Science that is supported by the National Science 501 Foundation under EPSCoR Grant \#1004057.

502

\section{References}

504 Aquilino, K., M. Bracken, M. Faubel \& J. Stachowicz, 2009. Local-scale nutrient regeneration facilitates seaweed growth on wave-exposed rocky shores in an upwelling system. Limnology and Oceanography 54: 309-317.

Berezina, N. A., I. G. Tsiplenkina, E. S. Pankova \& J. I. Gubelit, 2007. Dynamics of invertebrate communities on the stony littoral of the Neva Estuary (Baltic Sea) under macroalgal blooms and bioinvasions. Transitional Waters Bulletin 1: 65-76.

510 Boyer, K., P. Fong, A. Armitage \& R. Cohen, 2004. Elevated nutrient content of tropical 511 macroalgae increases rates of herbivory in coral, seagrass, and mangrove habitats. Coral $512 \quad$ Reefs 23: 530-538. 
513 Burkepile, D. E. \& M. E. Hay, 2006. Herbivore vs. nutrient control of marine primary

514 producers: context-dependent effects. Ecology 87: 3128-3139.

515 Burkepile, D. E. \& M. E. Hay, 2010. Impact of herbivore identity on algal succession and coral 516 growth on a Caribbean reef. PLoS ONE 5: e8963.

517 Calabretta, C. J. \& C. A. Oviatt, 2008. The response of benthic macrofauna to anthropogenic 518 stress in Narragansett Bay, Rhode Island: a review of human stressors and assessment of 519 community conditions. Marine Pollution Bulletin 56: 1680-1695.

520 Clark, K. L., G. M. Ruiz \& A. H. Hines, 2003. Diel variation in predator abundance, predation 521 risk and prey distribution in shallow-water estuarine habitats. Journal of Experimental $522 \quad$ Marine Biology and Ecology 287: 37-55.

523 Deacutis, C. 2008. Evidence of ecological impacts from excess nutrients in upper Narragansett 524 Bay. In: Desbonnet, A. \& B. A. Costa-Pierce (eds) Science for Ecosystem-Based 525 Management. Springer, New York: 349-381.

526 Dudley, T. L. 1992. Beneficial effects of herbivores on stream macroalgae via epiphyte removal. $527 \quad$ Oikos 65: 121-127.

528 Duffy, J. E. \& A. M. Harvilicz, 2001. Species-specific impacts of grazing amphipods in an 529

530 Duffy, J. E. \& M. E. Hay, 1991. Food and shelter as determinants of food choice by an 531 herbivorous marine amphipod. Ecology 72: 1286-1298.

532 Duffy, J. E., K. S. MacDonald, J. M. Rhode \& J. D. Parker, 2001. Grazer diversity, functional 533 redundancy, and productivity in seagrass beds: An experimental test. Ecology 82: 24175342434. 
Erickson, A. A., V. J. Paul, K. L. Van Alstyne \& L. M. Kwiatkowski, 2006. Palatability of macroalgae that use different types of chemical defenses. Journal of Chemical Ecology 32: 1883-1895.

Fox, S. E., M. Teichberg, I. Valiela \& L. Heffner, 2012. The relative role of nutrients, grazing, and predation as controls on macroalgal growth in the Waquoit Bay estuarine system. Estuaries and Coasts 35: 1193-1204.

Geertz-Hansen, O., K. Sand-Jensen, D. F. Hansen \& A. Christiansen, 1993. Growth and grazing control of abundance of the marine macroalga, Ulva lactuca L. in a eutrophic Danish estuary. Aquatic Botany 46: 101-109.

Granger, S. L., J. Mark, B. A. Buckley \& M. Schwartz, 2000. An assessment of eutrophication in Greenwich Bay, Vol 1. In M. Schwartz (ed.) Restoring water quality in Greenwich Bay: a whitepaper series. Rhode Island Sea Grant, Narragansett, R.I.

Gruner, D., J. E. Smith, E. Seabloom, S. A. Sandin, J. T. Ngai, H. Hillebrand, W. Harpole, J. J. Elser, E. Cleland, M. E. S. Bracken, E. Borer \& B. M. Bolker, 2008. A cross-system synthesis of consumer and nutrient resource control on producer biomass. Ecology Letters 11: 740-755.

Guidone, M. \& C. S. Thornber, 2013. Examination of Ulva bloom species richness and relative abundance reveals two cryptically co-occurring bloom species in Narragansett Bay, Rhode Island. Harmful Algae 24: 1-9.

Guidone, M., C. Thornber \& E. Field, 2010. Snail grazing facilitates growth of a bloom-forming alga. Marine Ecology Progress Series 420: 83-89. 
Guidone, M., C. S. Thornber \& E. Vincent, 2012. Snail grazing facilitates growth of two morphologically similar bloom-forming Ulva species through different mechanisms. Journal of Ecology 100: 1105-1112.

Guidone, M., C. Thornber, B. Wysor \& C. J. O'Kelly, 2013. Molecular and morphological diversity of Narragansett Bay (RI, USA) Ulva (Ulvales, Chlorophyta) populations. Journal of Phycology 49: 979-995.

Hauxwell, J., J. McClelland, P J. Behr \& I. Valiela, 1998. Relative importance of grazing and nutrient controls of macroalgal biomass in three temperate shallow estuaries. Estuaries $21: 347-360$.

Hauxwell, J., J. Cebrián, C. Furlong \& I. Valiela, 2001. Macroalgal canopies contribute to eelgrass (Zostera marina) decline in temperate estuarine ecosystems. Ecology 82: 10071022.

Hillebrand, H., D. Gruner, E. Borer, M. E. S. Bracken, E. Cleland, J. J. Elser, W. Harpole, J. Ngai, E. Seabloom, J. Shurin \& J. E. Smith, 2007. Consumer versus resource control of producer diversity depends on ecosystem type and producer community structure. Proceedings of the National Academy of Sciences USA 104: 10904-10909.

Hofmann, L., J. Nettleton, C. Neefus \& A. Mathieson, 2010. Cryptic diversity of Ulva (Ulvales, Chlorophyta) in the Great Bay Estuarine System (Atlantic USA): introduced and indigenous distromatic species. European Journal of Phycology 45: 230-239.

Horne, A., J. McClelland \& I. Valiela, 1994. The growth and consumption of macroalgae in estuaries: the role of invertebrate grazers along a nutrient gradient in Waquoit Bay, Massachusetts. Biological Bulletin 187: 279-280. 
Jormalainen, V., T. Honkanen, R. Koivikko \& J. Eränen, 2003. Induction of phlorotannin production in a brown alga: defense or resource dynamics? Oikos 103: 640-650.

Kamermans, P., E. J. Malta, J. M. Verschuure, L. Schrijvers, L. F. Lentz \& A. T. A. Lien, 2002. Effect of grazing by isopods and amphipods on growth of Ulva spp. (Chlorophyta). Aquatic Ecology 36: 425-433.

Karsten, U., C. Wiencke \& G. Kirst, 1991. Growth pattern and beta-dimethylsulfoniopropionate

586 (DMSP) content of marine macroalgae at different irradiances. Marine Biology 108: 151155.

Karsten, U., C. Wiencke \& G. O. Kirst, 1992. Dimethylsulfoniopropionate (DMSP) accumulation in green macroalgae from polar to temperate regions: interactive effects of light versus salinity and light versus temperature. Polar Biology 12: 603-607.

Korpinen, S., V. Jormalainen \& T. Honkanen, 2007. Effects of nutrients, herbivory, and depth on the macroalgal community in the rocky sublittoral. Ecology 88: 839-852.

Littler, M. M., D. S. Littler \& P. R. Taylor, 1995. Selective herbivore increases biomass of its prey: a chiton-coralline reef-building association. Ecology 76: 1666-1681.

Lotze, H. K. \& B. Worm, 2000. Variable and complementary effects of herbivores on different life stages of bloom-forming macroalgae. Marine Ecology Progress Series 200: 167-175.

Lyons, D., R. Scheibling \& K. L. Van Alstyne, 2010. Spatial and temporal variation in DMSP content in the invasive seaweed Codium fragile ssp. fragile: effects of temperature, light, and grazing. Marine Ecology Progress Series 417: 51-61.

McLenaghan, N., A. Tyler, U. Mahl, R. Howarth \& R. Marino, 2011. Benthic macroinvertebrate functional diversity regulates nutrient and algal dynamics in a shallow estuary. Marine Ecology Progress Series 426: 171-184. 
Morgan, J. A., A. B. Aguiar, S. Fox, M. Teichberg \& I. Valiela, 2003. Relative influence of grazing and nutrient supply on growth of the green macroalga Ulva lactuca in estuaries of Waquoit Bay, Massachusetts. Biological Bulletin 205: 252-253.

Neckles, H., R. Wetzel \& R. Orth, 1993. Relative effects of nutrient enrichment and grazing on epiphyte-macrophyte (Zostera marina L.) dynamics. Oecologia 93: 285-295.

Nelson, T. A., K. Haberlin, A. V. Nelson, H. Ribarich, R. Hotchkiss, K. L. Van Alstyne, L. Buckingham, D. J. Simunds \& K. Fredrickson, 2008. Ecological and physiological controls of species composition in green macroalgal blooms. Ecology 89: 1287-1298.

Nicotri, M. E. 1980 Factors involved in herbivore food preference. Journal of Experimental Marine Biology and Ecology 42: 13-26.

Norkko, J., E. Bonsdorff \& A. Norkko. 2000. Drifting algal mats as an alternative habitat for benthic invertebrates: species specific responses to a transient resource. Journal of Experimental Marine Biology and Ecology 248: 79-104.

Oczkowski, A. J., S. W. Nixon, K. Henry, P. DiMilla, M. Pilson, S. L. Granger, B. Buckley, C. Thornber, R. A. McKinney \& J. Chaves, 2008. Distribution and trophic importance of anthropogenic nitrogen in Narragansett Bay: an assessment using stable isotopes. Estuaries Coasts 31: 53-69.

Råberg, S. \& L. Kautsky, 2008. Grazer identity is crucial for facilitating growth of the perennial brown alga Fucus vesiculosus. Marine Ecology Progress Series 361: 111-118.

Russell, B. D. \& S. D. Connell, 2007. Response of grazers to sudden nutrient pulses in oligotrophic versus eutrophic conditions. Marine Ecology Progress Series 349: 73-80.

Sala, N. M., M. D. Bertness \& B. R. Silliman, 2008. The dynamics of bottom-up and top-down control in a New England salt marsh. Oikos 117: 1050-1056. 
624 Shurin, J. B., E. Borer, E. W. Seabloom, K. Anderson, C. A. Blanchette, B. Broitman, S. Cooper \& B. S. Halpern, 2002. A cross-ecosystem comparison of the strength of trophic cascades Ecology Letters 5: 785-791.

627 Sly, E. 2013. Dietary contribution of polychlorinated biphenyl contaminated Ulva to Fundulus heteroclitus in the New Bedford Harbor, MA, Superfund site. M.S. Thesis. Northeastern

Steneck, R. S. \& M. N. Dethier, 1994. A functional group approach to the structure of algalUniversity.

Thornber, C. S., E. Jones \& J. J. Stachowicz, 2008. Differences in herbivore feeding preferences across a vertical rocky intertidal gradient. Marine Ecology Progress Series 363: 51-62.

Valiela, I., J. McClelland, J. Hauxwell, P. J. Behr, D. Hersh \& K. Foreman, 1997. Macroalgal blooms in shallow estuaries: Controls and ecophysiological and ecosystem consequences. Limnology and Oceanography 42: 1105-1118.

Van Alstyne, K. L. \& L. T. Houser, 2003. Dimethylsulfide release during macroinvertebrate

643 Van Alstyne, K. L., G. V. Wolfe, T. L. Freidenburg, A. Neill \& C. Hicken, 2001. Activated 644 defense systems in marine macroalgae: evidence for an ecological role for DMSP cleavage. Marine Ecology Progress Series 213: 53-65. 
646

647

648

649

650

651

652

653

654

655

656

657

658

659

660

661

662

Van Alstyne, K. L., L. Koellermeier \& T. Nelson, 2007. Spatial variation in dimethylsulfoniopropionate (DMSP) production in Ulva lactuca (Chlorophyta) from the Northeast Pacific. Marine Biology 150: 1127-1135.

Van Alstyne, K. L., K. N. Pelletreau \& A. Kirby, 2009. Nutritional preferences override chemical defenses in determining food choice by a generalist herbivore, Littorina sitkana. Journal of Experimental Marine Biology and Ecology 379: 85-91.

Vermeij M. J. A., M. L. Dailer, S. M. Walsh, M. K. Donovan \& C. M. Smith, 2010. The effects of trophic interactions and spatial competition on algal community composition on Hawaiian coral reefs. Marine Ecology 31: 291-299.

Williams S. L. \& M. H. Ruckelshaus, 1993. Effects of nitrogen availability and herbivory on eelgrass (Zostera marina) and epiphytes. Ecology 74: 904-918.

Worm, B. \& H. K. Lotze, 2006. Effects of eutrophication, grazing, and algal blooms on rocky shores. Limnology and Oceanography 51: 569-579.

Yarrington, C. S., A. C. Tyler \& A. H. Altieri, 2013. Do snails facilitate bloom-forming macroalgae in a eutrophic estuary? Journal of Experimental Marine Biology and Ecology 446: $253-261$. 


\section{Figures}

664

665 Fig. 1 Map of Narragansett Bay showing the location of our herbivore exclusion field sites:

666 Chepiwanoxet (CH), Warwick City Park (WCP), and Oakland Beach Cove (OBC). Photos: C.

667 Deacutis

668 Fig. 2 Mean daily change in Ulva compressa wet mass ( $\pm 1 \mathrm{SE})$ in small (S), medium (M), and

669 large (L) mesh cages at Chepiwanoxet (CH), Warwick City Park (WCP), and Oakland Beach

670 Cove (OBC) during 2009 herbivore exclusion experiments: a) May, b) June, c) July, and d)

671 August.

672 Fig. 3 Mean abundance of the eight herbivores contributing most to the dissimilarity between

673 cage types and exclusion sites Chepiwanoxet $(\mathrm{CH})$, Warwick City Park (WCP), and Oakland

674 Beach Cove (OBC) in May, June, July, and August 2009 and June and July 2010: a)

675 Corophiidae, b) Gammaridae, c) Aoridae, d) Unidentified gammarid amphipods, e) Panopeidae,

676 f) Melitidae, g) Nereidae, and h) Palaemonetes vulgaris

677 Fig. 4 Mean daily change in Ulva compressa and U. rigida wet mass ( $\pm 1 \mathrm{SE})$ in small (S),

678 medium (M), and large (L) mesh cages during 2010 herbivore exclusion experiments: a) June

679 and b) July

680 Fig. 5 Mean daily change in Ulva compressa and U. rigida wet mass (per individual herbivore, \pm $6811 \mathrm{SE})$ in paired-choice feeding assays. * indicates a significant $(\mathrm{p}<0.05)$ difference 
Figure
Click here to download high resolution image

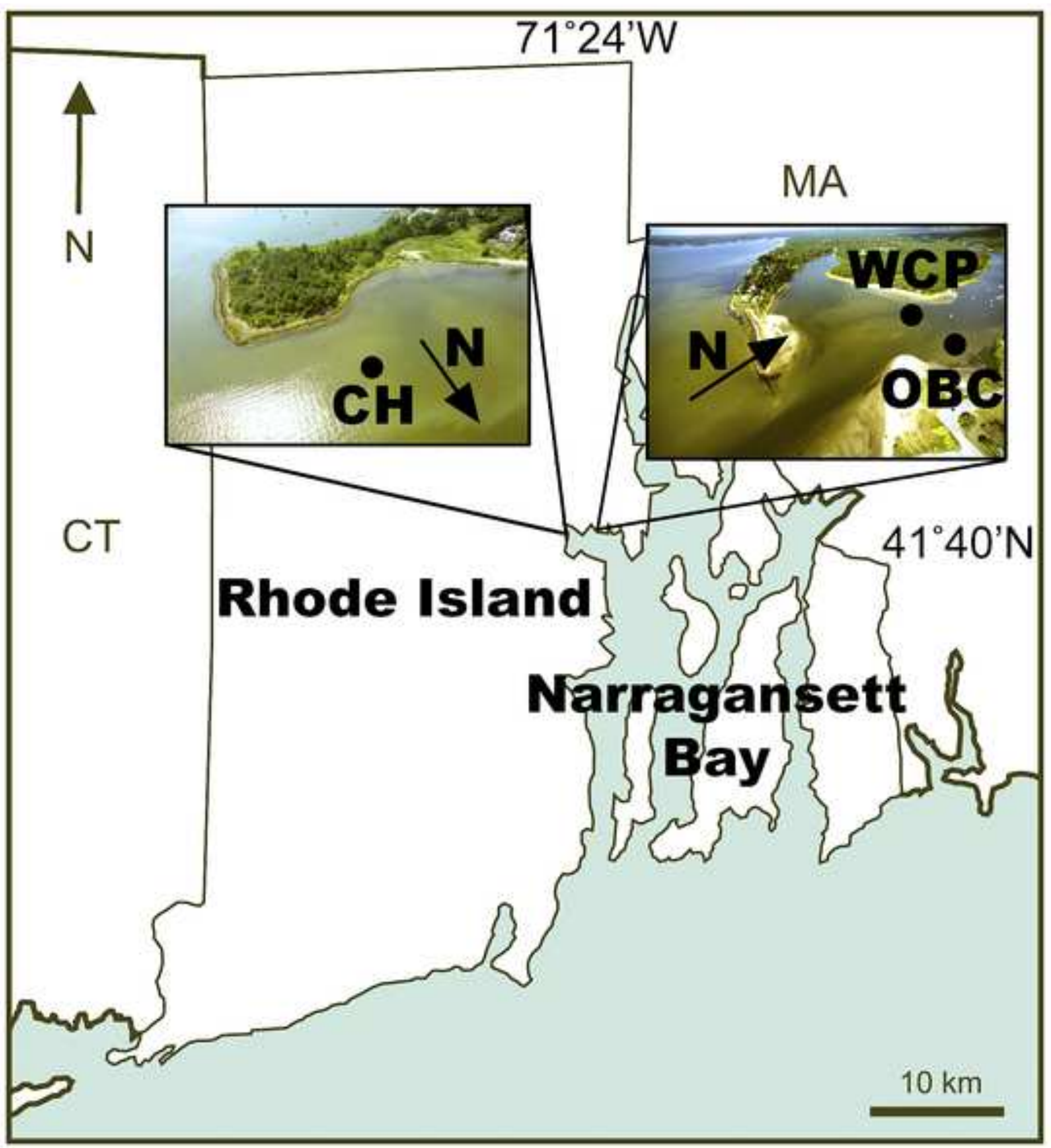




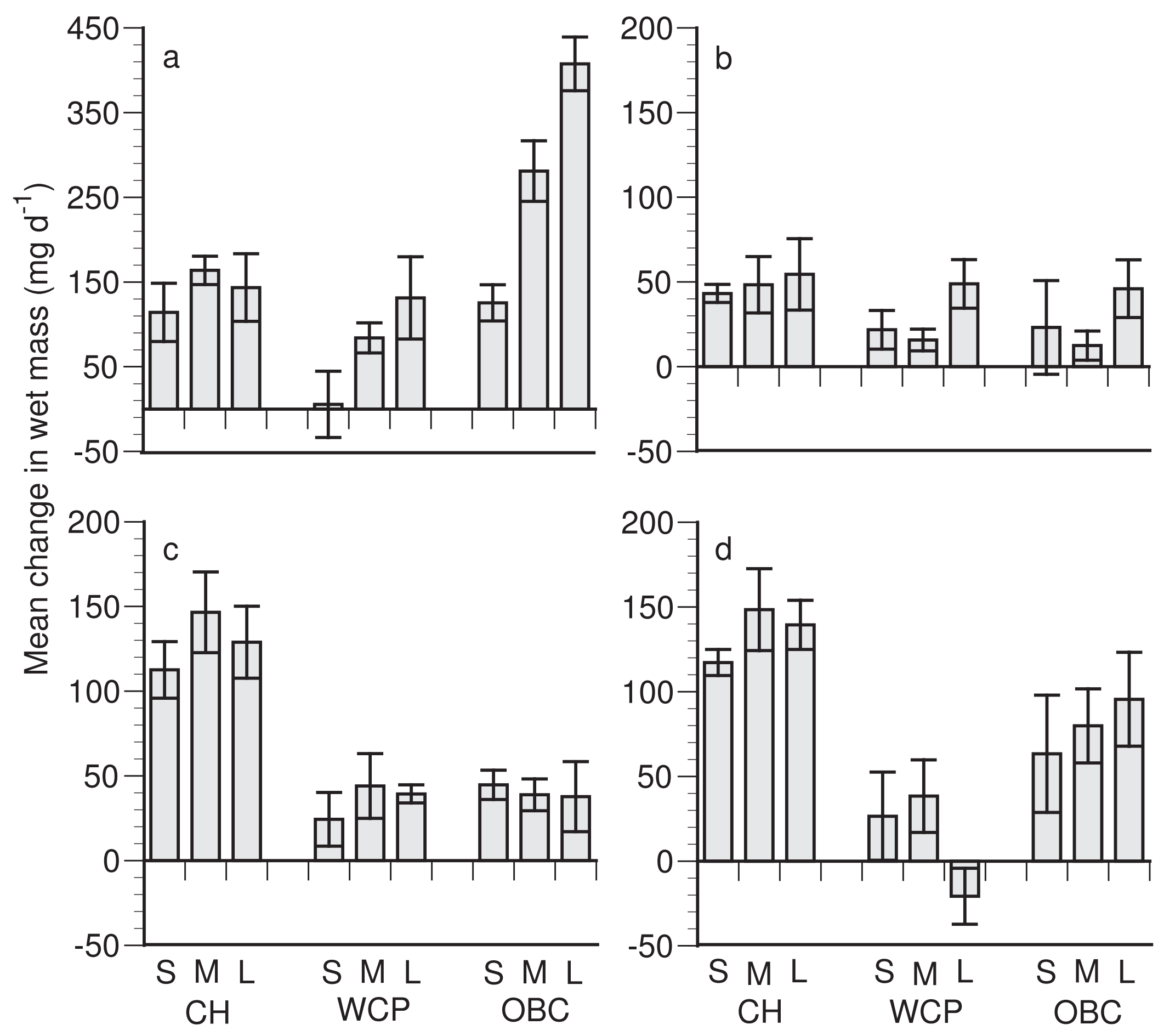


Click here to dow load Figure: Fig5.eps

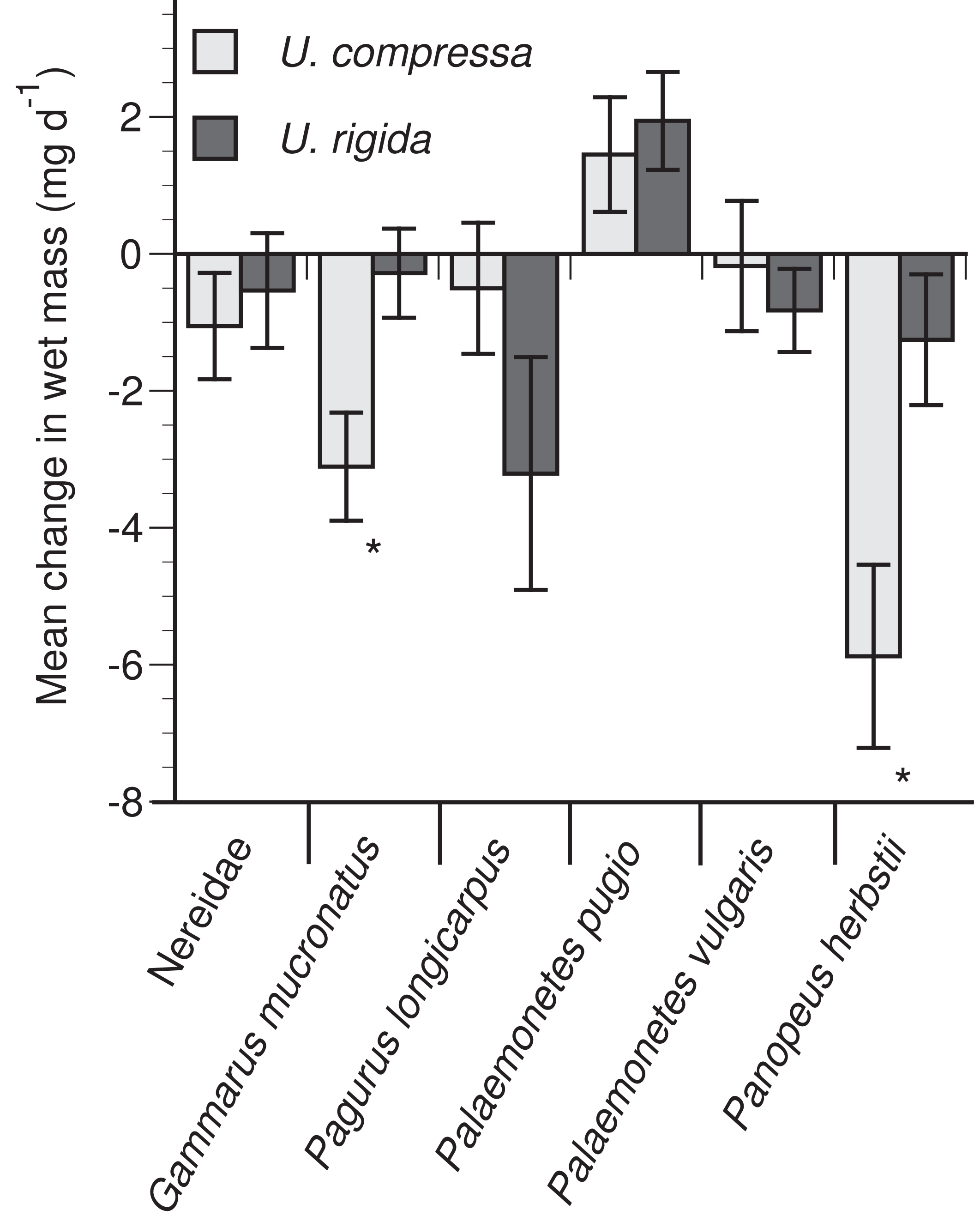


Table 1. Results of a) a three-way ANOVA on Ulva compressa growth during our 2009 herbivore exclusion experiments and b) a nested ANOVA on U. compressa and U. rigida growth during our 2010 herbivore exclusion experiments

\begin{tabular}{lrrrc} 
a) & df & \multicolumn{1}{c}{ SS } & \multicolumn{1}{l}{$l$} & $P$ \\
\hline Source & 3 & $386,266.43$ & 51.06 & $<0.0001$ \\
\hline Month & 2 & $187,807.01$ & 37.21 & $<0.0001$ \\
Site & 2 & $56,062.20$ & 11.11 & $<0.0001$ \\
Cage type & 6 & $290,652.97$ & 19.19 & $<0.0001$ \\
Month*Site & 6 & $105,767.61$ & 6.98 & $<0.0001$ \\
Month*Cage type & 4 & $22,564.29$ & 2.24 & 0.069 \\
Site*Cage type & 12 & $66,465.06$ & 2.19 & 0.015 \\
Month*Site*Cage type & 134 & $338,192.90$ & & \\
Error & & & & \\
\hline
\end{tabular}

b)

\begin{tabular}{lrrrc}
\hline Source & df & \multicolumn{1}{c}{ SS } & \multicolumn{1}{l}{} & $P$ \\
\hline Month & 1 & $4,818.37$ & 2.59 & 0.11 \\
Site & 2 & $107,000.88$ & 28.79 & $<0.0001$ \\
Cage type & 2 & $41,594.60$ & 7.70 & $<0.0001$ \\
Species [Cage type] & 3 & $42,905.20$ & 11.19 & $<0.0001$ \\
Month*Site & 2 & $45,162.94$ & 12.15 & $<0.0001$ \\
Month*Cage type & 2 & $68,701.45$ & 18.48 & $<0.0001$ \\
Month*Species [Cage type] & 3 & $25,855.26$ & 4.64 & 0.004 \\
Site*Cage type & 4 & $10,006.56$ & 1.35 & 0.26 \\
Site*Species [Cage type] & 6 & $2,267.73$ & 0.20 & 0.98 \\
Month*Site*Cage type & 4 & $20,507.03$ & 2.76 & 0.030 \\
Month*Site*Species [Cage type] & 6 & $29,567.29$ & 2.65 & 0.018 \\
Error & 140 & $260,182.24$ & & \\
\hline
\end{tabular}


Table 2. Ulva compressa and U. rigida tissue organic content

\begin{tabular}{|c|c|c|c|c|}
\hline Species & Year & Month & Site & $\%$ Organic $( \pm 1 \mathrm{SE})$ \\
\hline \multirow[t]{12}{*}{ U. compressa } & 2009 & May & $\mathrm{CH}$ & $66.07 \pm 1.06$ \\
\hline & & & WCP & $68.53 \pm 0.86$ \\
\hline & & & OCB & $68.25 \pm 1.34$ \\
\hline & & June & $\mathrm{CH}$ & $71.60 \pm 1.04$ \\
\hline & & & WCP & $74.37 \pm 0.71$ \\
\hline & & & OCB & $74.11 \pm 1.22$ \\
\hline & & July & $\mathrm{CH}$ & $76.42 \pm 1.12$ \\
\hline & & & WCP & $76.91 \pm 1.04$ \\
\hline & & & OCB & $75.66 \pm 1.15$ \\
\hline & & August & $\mathrm{CH}$ & $75.47 \pm 1.24$ \\
\hline & & & WCP & $79.94 \pm 1.80$ \\
\hline & & & OCB & $76.87 \pm 0.71$ \\
\hline \multirow[t]{6}{*}{ U. compressa } & 2010 & June & $\mathrm{CH}$ & $70.68 \pm 1.03$ \\
\hline & & & WCP & $69.68 \pm 1.35$ \\
\hline & & & OCB & $69.68 \pm 2.22$ \\
\hline & & July & $\mathrm{CH}$ & $69.70 \pm 1.11$ \\
\hline & & & WCP & $65.76 \pm 1.02$ \\
\hline & & & OCB & $60.30 \pm 4.34$ \\
\hline \multirow[t]{6}{*}{ U. rigida } & 2010 & June & $\mathrm{CH}$ & $69.59 \pm 2.03$ \\
\hline & & & WCP & $66.10 \pm 1.79$ \\
\hline & & & OCB & $67.08 \pm 2.49$ \\
\hline & & July & $\mathrm{CH}$ & $68.12 \pm 2.35$ \\
\hline & & & WCP & $59.86 \pm 3.51$ \\
\hline & & & OCB & $67.22 \pm 3.01$ \\
\hline
\end{tabular}




\section{Electronic Supplementary Material:}

Guidone $\mathrm{M}^{*}$, Thornber CS, Van Alstyne KL. Herbivore impacts on two morphologically similar bloom-forming Ulva species in a eutrophic bay. Hydrobiologia.

*For correspondence: michele.guidone@armstrong.edu; affiliation: Armstrong State University

Table S1. Results from two-way crossed ANOSIMs for differences among sites and cage types for each month in our 2009 (a, b) and 2010 (c, d) herbivore exclusion experiments. R-values close to 1.00 indicate complete separation between groups while R-values close to 0 indicate little separation between groups. * indicates a significant pairwise tests $(p<0.05)$. (a, c) Tests for differences between site groups across all cage type groups. (b, d) Tests for differences between cage type groups across all site groups

(a)

\begin{tabular}{|c|c|c|}
\hline & Chepiwanoxet & Warwick City Park Oakland Beach \\
\hline \multicolumn{3}{|c|}{ May: Global $\mathrm{R}=0.677^{*}$} \\
\hline \multicolumn{3}{|l|}{ Chepiwanoxet } \\
\hline Warwick City Park & $0.352 *$ & \\
\hline Oakland Beach & $0.367 *$ & 0.033 \\
\hline \multicolumn{3}{|c|}{ June: Global $\mathrm{R}=0.287^{*}$} \\
\hline \multicolumn{3}{|l|}{ Chepiwanoxet } \\
\hline Warwick City Park & $0.372 *$ & \\
\hline Oakland Beach & $0.416^{*}$ & 0.089 \\
\hline \multicolumn{3}{|c|}{ July: Global $\mathrm{R}=0.505^{*}$} \\
\hline \multicolumn{3}{|l|}{ Chepiwanoxet } \\
\hline Warwick City Park & $0.844^{*}$ & \\
\hline Oakland Beach & $0.587 *$ & 0.047 \\
\hline \multicolumn{3}{|c|}{ August: Global $\mathrm{R}=0.189 *$} \\
\hline \multicolumn{3}{|l|}{ Chepiwanoxet } \\
\hline Warwick City Park & $0.287 *$ & \\
\hline Oakland Beach & $0.281 *$ & -0.007 \\
\hline
\end{tabular}




\begin{tabular}{|c|c|c|c|}
\hline \multicolumn{4}{|l|}{ (b) } \\
\hline $\begin{array}{l}\text { Global R: } \\
\mathrm{P}=0.002\end{array}$ & Small Mesh & Medium Mesh & Large Mesh \\
\hline \multicolumn{4}{|c|}{ May: Global $\mathrm{R}=0.233^{*}$} \\
\hline \multicolumn{4}{|l|}{ Small Mesh } \\
\hline Medium Mesh & $0.248^{*}$ & & \\
\hline Large Mesh & $0.414 *$ & 0.031 & \\
\hline \multicolumn{4}{|c|}{ June: Global $\mathrm{R}=0.328^{*}$} \\
\hline \multicolumn{4}{|l|}{ Small Mesh } \\
\hline Medium Mesh & $0.234 *$ & & \\
\hline Large Mesh & $0.641 *$ & $0.123 *$ & \\
\hline \multicolumn{4}{|c|}{ July: Global $R=0.119^{*}$} \\
\hline \multicolumn{4}{|c|}{ Small Mesh } \\
\hline Medium Mesh & 0.066 & & \\
\hline Large Mesh & $0.266^{*}$ & 0.047 & \\
\hline \multicolumn{4}{|c|}{ August: Global $\mathrm{R}=0.133^{*}$} \\
\hline \multicolumn{4}{|l|}{ Small Mesh } \\
\hline Medium Mesh & $0.111 *$ & & \\
\hline Large Mesh & $0.255^{*}$ & $0.042 *$ & \\
\hline
\end{tabular}

(c)

\begin{tabular}{llll}
\hline & Chepiwanoxet & Warwick City Park & Oakland Beach \\
\hline June: Global R $=0.424^{*}$ & & & \\
$\quad$ Chepiwanoxet & & & \\
Warwick City Park & $0.430^{*}$ & 0.093 & \\
Oakland Beach & $0.738^{*}$ & & \\
July: Global R $=0.193^{*}$ & & & \\
$\quad$ Chepiwanoxet & & & \\
Warwick City Park & $0.356^{*}$ & & \\
Oakland Beach & $0.240^{*}$ & -0.016 & \\
\hline & & & \\
(d) & Small Mesh & Medium Mesh & Large Mesh \\
\hline & & & \\
\hline June: Global R $=0.299^{*}$ & & & \\
Small Mesh & & & \\
Medium Mesh & $0.330^{*}$ & 0.054 & \\
Large Mesh & $0.503^{*}$ & & \\
July: Global R $=0.216^{*}$ & & & \\
Small Mesh & & & \\
Medium Mesh & $0.365^{*}$ & & \\
Large Mesh & $0.351^{*}$ & -0.028 & \\
\hline
\end{tabular}


Table S2. Results from a two-way crossed SIMPER analysis for average differences in herbivore assemblages between a) sites and b) cage types during our 2009 and 2010 herbivore exclusion experiments. Only the five taxa contributing the largest percentage of dissimilarity to a pair-wise comparison are shown

\begin{tabular}{lrrr} 
a) & \multicolumn{3}{c}{ Percentage contribution to average } \\
dissimilarity between sites
\end{tabular}


Melitidae

8.79

7.79

9.53

Panopeidae

10.11

9.91

10.31

Unidentified gammarid

10.20

10.17

11.05

Average between site dissimilarity $\quad 66.45$

66.15

60.09

June 2010

Aoridae

Corophiidae

5.75

17.77

6.72

11.87

Gammaridae

7.16

19.06

11.87

Ilyanassa obsoleta

7.50

8.01

11.47

Melitidae

12.64

Panopeidae

7.71

5.69

4.41

15.59

6.26

5.21

7.16

Phyllodocidae

6.75

6.70

7.48

Streblospio benedicti

6.71

Unidentified gammarid

8.20

Average between site dissimilarity $\quad 52.29$

8.43

6.18

9.13

12.90

52.82

39.94

July 2010

Aoridae

Gammaridae

10.23

9.74

Ilyanassa obsoleta

17.19

Nereidae

8.37

10.79

7.38

11.44

9.49

11.78

11.09

18.04

7.82

Panopeidae

9.72

11.48

Unidentified gammarid

9.81

14.09

Average between site dissimilarity $\quad 64.40$

7.92

10.85

70.50

60.26

b)

\begin{tabular}{lccc}
\hline Between cage type dissimilarity & \multicolumn{3}{c}{$\begin{array}{c}\text { Percentage contribution to average } \\
\text { dissimilarity between cage types }\end{array}$} \\
\cline { 2 - 4 } Taxon & $\begin{array}{l}\text { Small- } \\
\text { Medium }\end{array}$ & $\begin{array}{c}\text { Small- } \\
\text { Large }\end{array}$ & $\begin{array}{c}\text { Medium- } \\
\text { Large }\end{array}$ \\
\hline May 2009 & 16.29 & 14.23 & 8.92 \\
Corophiidae & 10.43 & 10.64 & 15.23 \\
Gammaridae & 8.13 & 9.76 & - \\
Lacuna vincta & 6.56 & 6.48 & 11.17 \\
Nereidae & 8.21 & 6.59 & 6.46 \\
Panopeidae & 7.68 & 8.55 & 10.87 \\
Phyllodocidae & 7.59 & 7.76 & 10.21 \\
Unidentified gammarid & 65.94 & 71.19 & 60.65 \\
Average between cage type dissimilarity & & & \\
June 2009 & & & \\
Corophiidae & 9.03 & 7.87 & 4.95 \\
Gammaridae & 16.38 & 15.43 & 8.70
\end{tabular}


Palaemonetes vulgaris

$3.28 \quad 9.96$

11.12

Panopeidae

10.06

7.01

9.22

Phyllodocidae

7.49

8.71

7.43

Unidentified gammarid

11.58

10.76

14.01

Unidentified polychaete

9.60

5.53

9.59

76.68

62.12

July 2009

Aoridae

Corophiidae

10.43

9.75

Gammaridae

14.35

Melitidae

7.63

9.30

10.04

Unidentified gammarid

31.92

7.54

9.33

9.97

11.36

12.10

10.38

11.72

8.23

10.31

8.44

9.87

11.86

Average between cage type dissimilarity

38.07

33.24

August 2009

Corophiidae

8.22

14.56

7.31

2.79

14.43

10.83

Melitidae

60.05

9.19

9.08

13.07

9.35

7.10

6.62

Palaemonetes vulgaris

7.03

8.10

Panopeidae

12.95

10.39

Unidentified gammarid

10.27

11.07

67.91

60.41

June 2010

Aoridae

9.04

12.60

11.75

Corophiidae

12.03

8.75

10.24

Gammaridae

13.56

15.15

10.26

Ilyanassa obsoleta

7.13

3.54

8.16

Palaemonetes vulgaris

3.44

9.47

10.42

Panopeidae

8.83

10.62

7.71

Unidentified gammarid

10.83

9.84

8.18

51.72

42.16

July 2010

Aoridae

11.01

11.73

11.59

8.66

Gammaridae

10.53

14.23

8.17

Ilyanassa obsoleta

7.30

9.93

12.21

Nereidae

15.38

10.78

12.19

Panopeidae

9.48

14.95

13.37

Unidentified gammarid

12.02

8.21

Average between cage type dissimilarity

69.67

75.49

56.41 
Table S3. Average experimental temperatures $\left({ }^{\circ} \mathrm{C} \pm 1 \mathrm{SE}\right)$ at each field site.

\begin{tabular}{llll}
\hline & Chepiwanoxet & Warwick City Park & Oakland Beach \\
\hline June 2009 & $19.58 \pm 0.044$ & $19.25 \pm 0.057$ & $19.41 \pm 0.059$ \\
July 2009 & $23.58 \pm 0.040$ & $24.01 \pm 0.061$ & $24.16 \pm 0.081$ \\
August 2009 & $26.12 \pm 0.056$ & $26.78 \pm 0.065$ & $27.05 \pm 0.084$ \\
June 2010 & $22.90 \pm 0.099$ & $23.38 \pm 0.087$ & $23.96 \pm 0.099$ \\
July 2010 & $25.75 \pm 0.042$ & $26.41 \pm 0.058$ & $26.59 \pm 0.065$ \\
\hline
\end{tabular}


Table S4. Results from one-way SIMPER analyses for average similarity and differences between cage and net invertebrate assemblages during 2009 and 2010

\begin{tabular}{lrl}
\hline & Percent contribution & Cumulative percent \\
\hline Within sample similarity - 2009 & & \\
Cage-Average similarity: 35.31 & & \\
Mud crab & 27.04 & 27.04 \\
Corophiidae & 19.97 & 47.02 \\
Unidentifiable gammarid & 17.38 & 64.40 \\
Gammaridae & 15.50 & 79.90 \\
Melitidae & 5.16 & 85.06 \\
Phyllodocidae & 3.57 & 88.64 \\
Nereidae & 3.03 & 91.67 \\
Net - Average similarity: 45.70 & & \\
Ilyanassa obsoleta & 69.45 & 69.45 \\
Pagurus spp. & 13.11 & 82.56 \\
Crangon septemspinosa & 5.16 & 87.72 \\
Palaemonetes pugio & 3.87 & 91.59 \\
& & \\
Within sample similarity - 2010 & & \\
Cage- Average similarity: 37.28 & & \\
Gammaridae & 24.24 & 24.24 \\
Aoridae & 17.69 & 41.93 \\
Mud crabs & 17.02 & 58.95 \\
Unidentified gammarids & 9.48 & 68.42 \\
Corophiidae & 8.53 & 76.95 \\
Nereidae & 7.47 & 84.43 \\
Melitidae & 4.88 & 89.30 \\
Ilyanassa obsoleta & 3.90 & 93.20 \\
Net-Average similarity: 47.34 & & 89.73 \\
Ilyanassa obsoleta & 89.73 & 91.74 \\
Gammaridae & 2.00 & \\
\hline
\end{tabular}

\begin{tabular}{lcc}
\hline Between sample dissimilarity & \multicolumn{2}{c}{$\begin{array}{c}\text { Percentage contribution to average dissimilarity between } \\
\text { cage and net invertebrate samples }\end{array}$} \\
\cline { 2 - 3 } Taxon & 2009 & 2010 \\
\hline Aoridae & 3.87 & 11.00 \\
Corophiidae & 11.70 & 8.45 \\
Gammaridae & 10.16 & 14.55 \\
Crangon septemspinosa & 2.24 & - \\
Ilyanassa obsoleta & 12.08 & 14.27 \\
Melitidae & 5.42 & 5.65 \\
Mud crabs & 13.62 & 12.52 \\
\hline
\end{tabular}




\begin{tabular}{lrc}
\hline Nereidae & 4.22 & 7.09 \\
Pagurus spp. & 4.26 & - \\
Palaemonetes pugio & 3.03 & - \\
Palaemonetes vulgaris & 4.19 & 4.75 \\
Phyllodocidae & 4.43 & 3.98 \\
Unidentifiable gammarid & 10.07 & 8.18 \\
Unidentifiable polychaete & 2.90 & - \\
Total contribution of taxa & 92.19 & 90.46 \\
Average between sample type & 91.95 & 90.73 \\
dissimilarity & & \\
\hline
\end{tabular}


Fig. S5. Correlations between the change in Ulva wet mass $\left(\mathrm{mg} \mathrm{d}^{-1}\right)$ and total invertebrate abundance (per cage) in our herbivore exclusion experiments. A) 2009, B) 2010 U. compressa, C) 2010 U. rigida
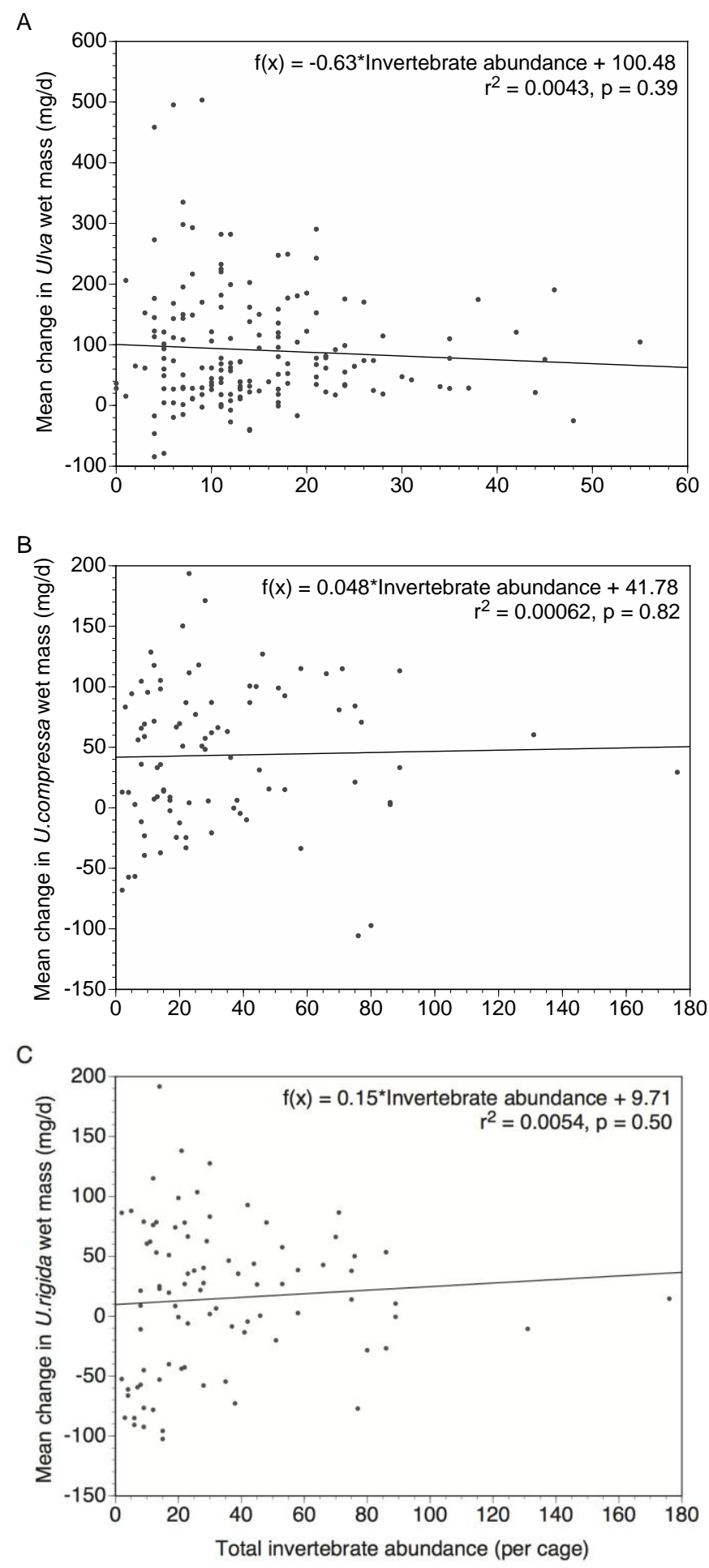
Fig. S6. Correlations between the change in Ulva compressa growth $\left(\mathrm{mg} \mathrm{d}^{-1}\right)$ and A) Gammaridae abundance in July 2009, B) Melitidae abundance in July 2009, and C) Panopeidae mud crab abundance in July 2010. D) Correlation between $U$. rigida growth $\left(\mathrm{mg} \mathrm{d}^{-1}\right)$ and Panopeidae mud crab abundance in July 2010
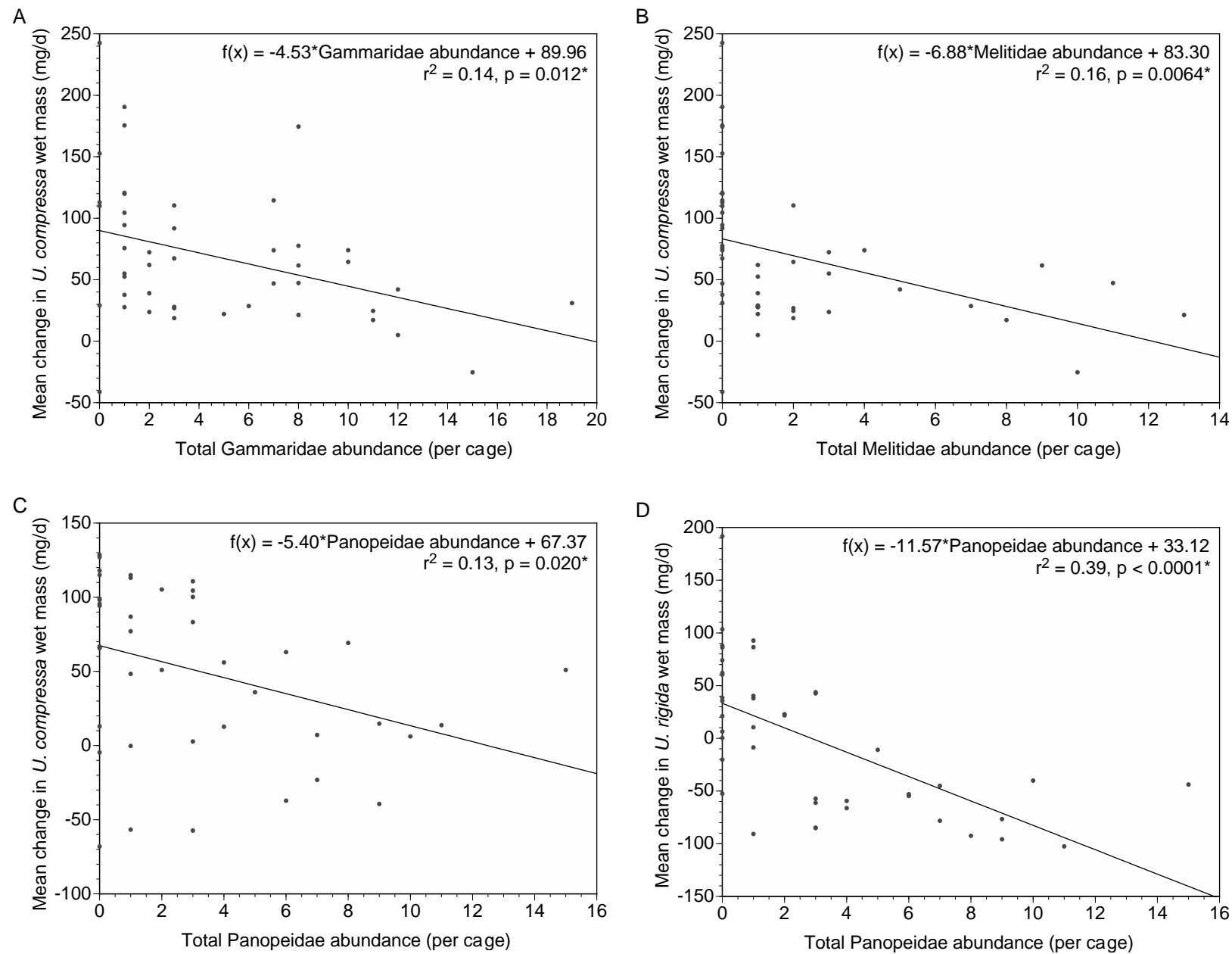